\title{
Multiphasic Analysis of Xanthomonads Causing Bacterial Spot Disease on Tomato and Pepper in the Caribbean and Central America: Evidence for Common Lineages Within and Between Countries
}

\author{
H. Bouzar, J. B. Jones, R. E. Stall, F. J. Louws, M. Schneider, J. L. W. Rademaker, F. J. de Bruijn, and L. E. Jackson
}

First and second authors: Gulf Coast Research and Education Center, University of Florida, Bradenton 34203; third author: Department of Plant Pathology, University of Florida, Gainesville 32611; fourth author: Department of Plant Pathology, North Carolina State University, Raleigh 27695; fourth, fifth, sixth, and seventh authors: MSU-DOE Plant Research Laboratory, Michigan State University, East Lansing 48824; seventh author: Department of Microbiology, Michigan State University, East Lansing 48824; and eighth author: AgriPhi, Inc., 160 North Main, Logan, UT 84321.

Current address of H. Bouzar: Sakata Seed America, Inc., 105 Boronda Road, Salinas, CA 93907.

Accepted for publication 5 January 1999.

\begin{abstract}
Bouzar, H., Jones, J. B., Stall, R. E., Louws, F. J., Schneider, M., Rademaker, J. L. W., de Bruijn, F. J., and Jackson, L. E. 1999. Multiphasic analysis of xanthomonads causing bacterial spot disease on tomato and pepper in the Caribbean and Central America: Evidence for common lineages within and between countries. Phytopathology 89:328-335.

Four hundred thirty-three xanthomonad strains isolated from tomato or pepper plants from 32 different fields in four Caribbean and Central American countries were screened for the ability to hydrolyze starch and sodium polypectate and for resistance to copper and streptomycin. Of these, 95 representative strains were further characterized by various phnetic tests, and 63 of these strains were then analyzed by genomic fingerprinting. Most of the strains (>90\%) were tolerant to copper. However, there was much more variability in sensitivity to streptomycin. All strains in Guadeloupe and $93 \%$ of the strains in Barbados were sensitive to streptomycin. The majority of strains were typical Xanthomonas cam-

pestris pv. vesicatoria group A strains. In Barbados, however, a unique group of strains was identified that was serologically similar to group A strains but was amylolytic. These strains were designated A1. The occurrence of $X$. campestris pv. vesicatoria group B strains in Central America was found to be limited to two fields in Costa Rica and one in Guatemala. No group B strains were identified in the Caribbean, in contrast to common occurrence in the central United States and in South America. T3 strains were not found in this study, despite the recent increase of such strains in Florida and Mexico. Unique strains from Costa Rica belonging to the $X$. gardneri group were identified. Little linkage was found among phenotypic and rep-polymerase chain reaction (rep-PCR) genomic fingerprinting profiles of the pathogens except at the species/pathovar level; strains displaying virtually identical fingerprint profiles were found to correspond to distinct races and vice versa. The rep-PCR genomic fingerprinting analyses suggest that certain lineages may have evolved or predominated in specific regions or specific countries.
\end{abstract}

Bacterial spot disease of pepper (Capsicum annuum L.) and tomato (Lycopersicon esculentum Mill.) can cause significant losses when warm temperatures and rainy weather occur $(14,27)$. The disease is observed worldwide in pepper- and tomato-production areas $(4,9)$. Integrated disease management strategies have relied on the use of pathogen-free seed, sanitation, and other cultural practices such as crop debris burial and crop rotation $(7,14,36)$. However these practices do not provide sufficient control of disease and have not been generally adopted by commercial growers. Chemical control strategies have also been employed including the use of copper and streptomycin sprays $(13,42)$, which has resulted in the development of resistant bacterial strains $(13,22,39,42)$.

The development of host-determined pathogen resistance consttutes another important approach to manage bacterial spot disease. Genetic sources of bacterial spot resistance have been identified in both pepper and tomato $(23,34)$. However, virulent strains of Xanthomonas campestris pv. vesicatoria occur naturally $(4,45)$ and, in some cases, have emerged as predominant populations in the absence of selection pressure $(12,15,26)$ or as a result of host-selective pressure (17).

The genetic diversity of the organism or organisms causing bacterial spot disease has complicated the development of durable host

Corresponding author: J. B. Jones; E-mail address: jbjones@ nersp.nerdc.ufl.edu

Publication no. P-1999-0208-04R

(C) 1999 The American Phytopathological Society resistance. Bacterial spot disease is caused by three different species $(38,40)$. Originally thought to be a homogeneous group of strains based on pathogenicity and bacteriological determinative tests (6), the majority of strains once considered to be members of $X$. campestris pv. vesicatoria belong to two genetically distinct groups, named A and B (38), and have been classified as X. axonopodis pv. vesicatoria and $X$. vesicatoria, respectively (43); although, in this paper, they will all be referred to as $X$. campestris pv. vesicatoria. These two groups can be rapidly and reliably distinguished using rep-polymerase chain reaction (rep-PCR) genomic fingerprinting $(19,20)$ and have limited genetic diversity within each group. The two groups also differ phenotypically according to utilization of cis-aconitic acid, reaction to monoclonal antibodies (MAbs), hypersensitive reaction (HR) on tomato, amylolytic and pectolytic activity, and whole-cell protein profiles in sodium dodecyl sulfatepolyacrylamide gel electrophoresis (SDS-PAGE) analysis $(2,4)$. A third species, $X$. gardneri, which causes lesions on tomato and pepper, was originally described in 1957 (40) and is genetically distinct from the neopathotype strain of $X$. campestris pv. vesicatoria (11); however, this species has not been a major pathogen since its discovery in 1957.

Numerous races of the bacterial spot pathogen have been identified based on their pathogenic reaction on pepper and tomato genotypes $(2,4,23)$. Strains are pathogenic on tomato only, pepper only, or both hosts $(4,23)$. Currently, nine pepper races and three tomato races have been identified $(4,15,17,23,32)$. Certain races of the pathogen have been found to correspond with a particular pheno- 
typic group (38). For example, tomato race 1 (T1) strains have been shown to belong to group A, and tomato race 2 (T2) strains belong to group B. A third group, designated group C, was identified in Florida in 1991 (15) as tomato race 3 (T3). It was similar to group B based on the ability to degrade pectate and hydrolyze starch; however, it was distinct from group A and B based on its protein profiles and reactivity with MAbs (12; J. B. Jones, H. Bouzar, and R. E. Stall, unpublished data).

As a result of the complex genetic diversity of the pathogen, current management strategies have been limited in efficacy for controlling bacterial spot of pepper and tomato. The development and implementation of an integrated disease management program would include the use of host-specific resistances in different production regions; however, deployment of this resistance would clearly depend on a detailed understanding of the genetic diversity of the pathogen (18). In this study, we have, therefore, used a multiphasic taxonomic approach to characterize indigenous Xanthomonas spp. populations associated with bacterial spot disease of pepper or tomato isolated from fields throughout Central America and the Caribbean. Our objectives were to (i) characterize pepper and tomato races of the pathogen, (ii) determine the presence and prevalence of copper and streptomycin resistance in bacterial strains causing bacterial spot in these regions, (iii) expand our knowledge about the relationship between phenotypic and genomic fingerprinting characteristics of bacteria causing bacterial spot disease on tomato and pepper plants, and (iv) determine the geographical distribution of phenotypic and genomic fingerprint groups.

Here we report on the presence of strains in the Caribbean and Central America with common lineages that also have similar phenotypic groups and belong to the same serovar. Also, we report on the presence of significant genomic fingerprint and phenotypic variation in Central America.

\section{MATERIALS AND METHODS}

Isolation of bacterial strains. Bacterial samples were collected from lesions of leaves and fruits of tomato and pepper plants grown in production fields in the Caribbean (Barbados, Guadeloupe, the U.S. Virgin Islands of St. Croix, and Puerto Rico) and Central America (Costa Rica, Guatemala, and Nicaragua). As many as 20 samples were processed for each field. The number of fields surveyed and the origin of the strains analyzed are presented in Table 1. Bacteria were isolated by triturating a lesion in a drop of sterile tap water and streaking the resulting suspension on nutrient agar (NA) (Difco Laboratories, Detroit) plates. Single, yellow colonies were purified by repeated streaking on NA. All strains were stored in $15 \%$ aqueous glycerol at $-70^{\circ} \mathrm{C}$ and regrown on NA plates prior to further analysis.

Phenotypic characterization. All Xanthomonas strains from each field were characterized by testing for the ability to (i) hydrolyze $1 \%$ starch in 2 days, (ii) degrade sodium polypectate, (iii) react with a panel of six MAbs, and (iv) grow on NA medium amended with either $200 \mu \mathrm{g}$ of $\mathrm{CuSO}_{4} \cdot 5 \mathrm{H}_{2} \mathrm{O}$ per ml or $25 \mu \mathrm{g}$ of streptomycin sulfate per $\mathrm{ml}$. These tests were performed as described previously $(2-4,38)$. Two to four representative strains were selected from each field for further analyses as defined below.

"Metabolic fingerprints" were obtained from the analysis of the oxidation pattern of 95 carbon sources on a GN Microplate (Bio$\log$ Inc., Hayward, CA). These metabolic fingerprints were subjected to cluster analysis to determine relationships between strains, as previously described $(1,4)$. The strains also were assayed for the presence of "group-specific protein bands" in whole-cell protein profiles as described by Bouzar et al. (2). Group A strains express a 32-kDa protein band, whereas group B strains produce a $27-\mathrm{kDa}$ protein band. In addition, the pathogenic race affiliation of the strains was determined as described by Bouzar et al. (4), using a differential set of pepper and tomato genotypes including the pepper lines Early Calwonder (ECW), ECW-10R, ECW-20R, and
ECW-30R and the tomato genotypes Walter and Hawaii 7998. Pepper and tomato races are designated by a $\mathrm{P}$ and $\mathrm{T}$, respectively, and number indicating the specific race. Those strains that attack both hosts have PT as their designation, followed by numbers for the specific races.

Representative strains were also typed using a set of 26 bacteriophages isolated from soil, diseased plant material, and sewage in Florida. This collection of phages was screened against a panel of six strains representative of the three serovars (4) identified among $X$. campestris pv. vesicatoria group A strains. Upon repeated attempts, no phages were isolated in this study that reacted with the group B strains. Susceptibility of the different strains to each phage was tested by adding a $5-\mu$ l phage suspension $\left(\sim 10^{10} \mathrm{PFU} / \mathrm{ml}\right)$ to a spot on the soft NA (7.5 g of agar per $1,000 \mathrm{ml})$ amended with bacterial cells $\left(10^{8} \mathrm{CFU} / \mathrm{ml}\right)$ from a 24 -h-old culture. The plates were incubated $24 \mathrm{~h}$ at $28^{\circ} \mathrm{C}$, and phage reactions were scored using a scale from 0 to 3 , in which $0=$ no phage activity, $1=$ lysogenic plaque formation, 2 = individual lytic plaques, and $3=$ confluent lytic plaques. Comparative data for each phage-strain com-

TABLE 1. Characteristics of strains causing bacterial spot on tomato and pepper grown in the Caribbean basin

\begin{tabular}{|c|c|c|c|c|c|}
\hline Country & $\begin{array}{l}\text { No. of } \\
\text { fields }\end{array}$ & $\begin{array}{l}\text { No. of } \\
\text { strains }\end{array}$ & $\operatorname{Str}^{\mathrm{y}}$ & $\mathrm{Amy} / \mathrm{Pec}^{\mathrm{z}}$ & Serovar \\
\hline \multicolumn{6}{|c|}{ Barbados } \\
\hline & $6 \mathrm{~T}$ & 19 & 14 & 0 & A1 \\
\hline & $7 \mathrm{P}$ & 13 & 0 & 0 & A1 \\
\hline & $8 \mathrm{P}$ & 17 & 0 & 17 & A1 \\
\hline & $9 \mathrm{~T}$ & 15 & 0 & 0 & A1 \\
\hline & $10 \mathrm{P}$ & 15 & 0 & 0 & A1 \\
\hline & $11 \mathrm{~T}$ & 11 & 0 & 0 & A1 \\
\hline \multicolumn{6}{|c|}{ Costa Rica } \\
\hline & $2 \mathrm{~T}$ & 14 & 3 & 0 & B1 \\
\hline & $3 \mathrm{~T}$ & 7 & 6 & 9 & B1 \\
\hline & & 1 & 1 & 1 & B0 \\
\hline & $4 \mathrm{P}$ & 9 & 1 & 0 & A1 \\
\hline & $5 \mathrm{~T}$ & 13 & 12 & 0 & A1 \\
\hline & $6 \mathrm{P}$ & 10 & 10 & 0 & A1 \\
\hline & $7 \mathrm{P}$ & 10 & 4 & 0 & A1 \\
\hline \multicolumn{6}{|c|}{ Guadeloupe } \\
\hline & $1 \mathrm{~T}$ & 17 & 0 & 0 & A1 \\
\hline & $2 \mathrm{~T}$ & 10 & 0 & 0 & A1 \\
\hline & & 1 & 0 & 0 & A3 \\
\hline & $2 \mathrm{P}$ & 5 & 0 & 0 & A1 \\
\hline & $3 \mathrm{~T}$ & 19 & 0 & 0 & A1 \\
\hline & $4 \mathrm{~T}$ & 12 & 0 & 0 & A1 \\
\hline & $4 \mathrm{P}$ & 4 & 0 & 0 & A1 \\
\hline & $5 \mathrm{~T}$ & 11 & 0 & 0 & A1 \\
\hline & $5 \mathrm{P}$ & 5 & 0 & 0 & A1 \\
\hline \multicolumn{6}{|c|}{ Guatemala } \\
\hline & $11 \mathrm{~T}$ & 1 & 0 & 0 & A1 \\
\hline & & 5 & 5 & 5 & B1 \\
\hline & & 12 & 12 & 12 & B2 \\
\hline & & 1 & 0 & 0 & A1 \\
\hline \multicolumn{6}{|c|}{ Nicaragua } \\
\hline & $9 \mathrm{~T}$ & 17 & 17 & 0 & A1 \\
\hline & $10 \mathrm{~T}$ & 20 & 20 & 0 & A1 \\
\hline \multicolumn{6}{|c|}{ Puerto Rico } \\
\hline & $1 \mathrm{P}$ & 20 & 0 & 0 & A1 \\
\hline & $2 \mathrm{P}$ & 11 & 0 & 0 & A1 \\
\hline & & 6 & 5 & 0 & A3 \\
\hline & $3 \mathrm{P}$ & 10 & 0 & 0 & A1 \\
\hline & & 2 & 1 & 0 & A3 \\
\hline & $4 \mathrm{P}$ & 19 & 18 & 0 & A3 \\
\hline & $5 \mathrm{P}$ & 17 & 16 & 0 & A3 \\
\hline & $6 \mathrm{P}$ & 3 & 2 & 0 & A1 \\
\hline & & 17 & 17 & 0 & A3 \\
\hline \multicolumn{6}{|c|}{ U.S. Virgin Islands } \\
\hline & $7 \mathrm{~T}$ & 17 & 17 & 0 & A3 \\
\hline & $8 \mathrm{~T}$ & 1 & 1 & 0 & A1 \\
\hline & & 16 & 16 & 0 & A3 \\
\hline
\end{tabular}

${ }^{x}$ Fields planted with $\mathrm{T}=$ tomato or $\mathrm{P}=$ pepper.

y $\mathrm{Str}=$ resistance to streptomycin.

${ }^{\mathrm{z}}$ Amy/Pec $=$ amylolytic and pectolytic activities. 
bination were tabulated, and the similarity coefficient between two strains was calculated using the SIMINT program from NTSYS-pc (version 1.80; Exeter Software, Setauket, NY). Cluster analysis by the unweighted pair group method was performed using the SAHN program from NTSYS-pc (version 1.80).

Genomic fingerprinting analysis. A total of 63 strains isolated from the Caribbean and Central America and three reference strains were subjected to rep-PCR genomic fingerprinting using primer sets corresponding to the BOX, ERIC, and REP elements (44). Representative $X$. campestris pv. vesicatoria strains of the three groups used for comparison in this study included group A strain Xv 153 (T1), group B strain Xv $1111=$ ATCC 35937 (T2), and group C strain Xv 938 (T3) (14). Isolation of total genomic DNA, rep-PCR, and electrophoresis conditions were as described $(21,28$, 44). Briefly, $50 \mathrm{ng}$ of purified DNA was used as a template in a $25-\mu$ reaction mixture containing 50 pmol of each primer, $1.25 \mathrm{mM}$ deoxynucleoside triphosphates, and 2 units of AmpliTaq DNA polymerase (Perkin-Elmer Corp., Norwalk, CT) in a reaction buffer

TABLE 2. Characteristics of representative strains causing bacterial spot on tomato, pepper, or both grown in the Caribbean basin

\begin{tabular}{|c|c|c|c|c|c|}
\hline Country & $\begin{array}{l}\text { No. of } \\
\text { fields }\end{array}$ & $\begin{array}{l}\text { No. of } \\
\text { strains }\end{array}$ & $\begin{array}{c}\text { Group-specific } \\
\text { protein }^{y}\end{array}$ & $\begin{array}{l}\text { Biolog } \\
\text { group }^{z}\end{array}$ & Race \\
\hline \multicolumn{6}{|l|}{ Barbados } \\
\hline & $6 \mathrm{~T}$ & 4 & $32 \mathrm{kDa}$ & II & T1P0 \\
\hline & $7 \mathrm{P}$ & 4 & $32 \mathrm{kDa}$ & II & T1P1 \\
\hline & $8 \mathrm{P}$ & 4 & $25 \mathrm{kDa}$ & I & $\mathrm{T} 1 \mathrm{P} 4$ \\
\hline & $9 \mathrm{~T}$ & 4 & $32 \mathrm{kDa}$ & II & T1P0, T1P1 \\
\hline & $10 \mathrm{P}$ & 4 & $32 \mathrm{kDa}$ & II & T1P1 \\
\hline & $11 \mathrm{~T}$ & 4 & $32 \mathrm{kDa}$ & II & \\
\hline \multicolumn{6}{|c|}{ Costa Rica } \\
\hline & $2 \mathrm{~T}$ & 4 & $27 \mathrm{kDa}$ & $\mathrm{V}$ & $\mathrm{P} 1$ \\
\hline & & 3 & $27 \mathrm{kDa}$ & V & $\mathrm{P} 1$ \\
\hline & $3 \mathrm{~T}$ & 4 & $27 \mathrm{kDa}$ & III & $\mathrm{T} 2$ \\
\hline & $4 \mathrm{P}$ & 4 & $32 \mathrm{kDa}$ & II & $\mathrm{P} 1, \mathrm{~T} 1 \mathrm{P} 1$ \\
\hline & $5 \mathrm{~T}$ & 4 & $32 \mathrm{kDa}$ & II & T1P2 \\
\hline & $6 \mathrm{P}$ & 4 & $32 \mathrm{kDa}$ & II & $\mathrm{P} 1$ \\
\hline & $7 \mathrm{P}$ & 4 & $32 \mathrm{kDa}$ & II & T1P1, P1 \\
\hline \multicolumn{6}{|c|}{ Guadeloupe } \\
\hline & $1 \mathrm{~T}$ & 4 & $32 \mathrm{kDa}$ & II & T1P1 \\
\hline & $2 \mathrm{~T}$ & 3 & $32 \mathrm{kDa}$ & II & T1P1 \\
\hline & & 1 & $32 \mathrm{kDa}$ & II & $\mathrm{T} 1$ \\
\hline & $2 \mathrm{P}$ & 2 & $32 \mathrm{kDa}$ & II & P1, T1P1 \\
\hline & $3 \mathrm{~T}$ & 3 & $32 \mathrm{kDa}$ & II & T1P1 \\
\hline & $4 \mathrm{~T}$ & 3 & $32 \mathrm{kDa}$ & II & T1P1 \\
\hline & $4 \mathrm{P}$ & 2 & $32 \mathrm{kDa}$ & II & T1P1 \\
\hline & $5 \mathrm{~T}$ & 2 & $32 \mathrm{kDa}$ & II & T1P1, T1P3 \\
\hline & $5 \mathrm{P}$ & 2 & $32 \mathrm{kDa}$ & II & T1P1, T1P3 \\
\hline \multicolumn{6}{|c|}{ Guatemala } \\
\hline & $11 \mathrm{~T}$ & 1 & $32 \mathrm{kDa}$ & II & T1P2 \\
\hline & & 1 & $27 \mathrm{kDa}$ & III & $\mathrm{T} 2$ \\
\hline & & 3 & $27 \mathrm{kDa}$ & III, IV & $\mathrm{T} 2$ \\
\hline & & 1 & $32 \mathrm{kDa}$ & II & $\mathrm{T} 1 \mathrm{P} 2$ \\
\hline \multicolumn{6}{|c|}{ Nicaragua } \\
\hline & $9 \mathrm{~T}$ & 5 & $32 \mathrm{kDa}$ & II & $\mathrm{T} 1 \mathrm{P} 2, \mathrm{~T} 1 \mathrm{P} 3$ \\
\hline & $10 \mathrm{~T}$ & 5 & $32 \mathrm{kDa}$ & II & T1P2, T1P3 \\
\hline \multicolumn{6}{|c|}{ Puerto Rico } \\
\hline & $1 \mathrm{P}$ & 4 & $32 \mathrm{kDa}$ & II & P1, T1P1 \\
\hline & $2 \mathrm{P}$ & 1 & $32 \mathrm{kDa}$ & II & $\mathrm{T} 1 \mathrm{P} 1$ \\
\hline & & 3 & $32 \mathrm{kDa}$ & II & P1, T1P0 \\
\hline & $3 \mathrm{P}$ & 3 & $32 \mathrm{kDa}$ & II & P1, P3 \\
\hline & & 1 & $32 \mathrm{kDa}$ & II & T1P0 \\
\hline & $4 \mathrm{P}$ & 3 & $32 \mathrm{kDa}$ & II & T1P0 \\
\hline & $5 \mathrm{P}$ & 4 & $32 \mathrm{kDa}$ & II & T1P0 \\
\hline & $6 \mathrm{P}$ & 1 & $32 \mathrm{kDa}$ & II & $\mathrm{P} 1$ \\
\hline & & 1 & $32 \mathrm{kDa}$ & II & P0, T1P0 \\
\hline \multicolumn{6}{|c|}{ U.S. Virgin Islands } \\
\hline & $7 \mathrm{~T}$ & 5 & $32 \mathrm{kDa}$ & II & $\mathrm{T} 1$ \\
\hline & $8 \mathrm{~T}$ & 1 & $32 \mathrm{kDa}$ & II & $\mathrm{T} 1$ \\
\hline & & 5 & $32 \mathrm{kDa}$ & II & $\mathrm{T} 1$ \\
\hline
\end{tabular}

${ }^{\mathrm{x}}$ Fields planted with $\mathrm{T}=$ tomato or $\mathrm{P}=$ pepper.

y Size of protein band in sodium dodecyl sulfate-polyacrylamide gel electrophoresis.

${ }^{\mathrm{z}}$ Cluster number from the Biolog dendrogram (Fig. 3). with $10 \%$ dimethyl sulfoxide (vol/vol). PCR mixtures were overlaid with $25 \mu \mathrm{l}$ of mineral oil (Sigma M3516; Sigma Chemical Co., St. Louis). PCR amplification reactions were performed with a Perkin-Elmer 480 DNA thermal cycler (Perkin-Elmer Corp.) using the following conditions: an initial denaturation at $95^{\circ} \mathrm{C}$ for $7 \mathrm{~min}$; 30 cycles consisting of $94^{\circ} \mathrm{C}$ for $1 \mathrm{~min}$ and annealing at 40 , 52 , or $53^{\circ} \mathrm{C}$ for $1 \mathrm{~min}$ with either REP, ERIC, or BOX primers, respectively; extension at $65^{\circ} \mathrm{C}$ for $8 \mathrm{~min}$; and a single final extension at $65^{\circ} \mathrm{C}$ for $15 \mathrm{~min}$, followed by cooling at $4^{\circ} \mathrm{C}$.

A $6-\mu \mathrm{l}$ aliquot of amplified PCR products was separated by gel electrophoresis at $4{ }^{\circ} \mathrm{C}$ on $1.5 \%$ agarose gels in $0.75 \%$ Tris-acetate buffer for 15 to $18 \mathrm{~h}$ at $5 \mathrm{~V} / \mathrm{cm}$, stained with ethidium bromide, and photographed on a UV transilluminator using Polaroid Type 55 film (Polaroid Corp., Cambridge, MA). Computer-assisted pattern analysis was performed as described (28-30). Polaroid photographs of the stained agarose gels were digitized and subjected to computer-assisted analysis using the commercially available GelCompar software (version 4.0; Applied Maths, Kortrijk, Belgium). Gels were normalized using the same standards (Lambda/HindIII, pUC19/TaqI, and pUC19/SauIIIA; Stratagene Inc., La Jolla, CA) loaded on both sides and in the center of 30-lane gels. The "rolling disk" background subtraction method was applied. The BOX-, ERIC-, and REP-PCR genomic fingerprints were linearly combined using the "combined gel" option of GelCompar. The similarity between pairs of linearly combined fingerprints was calculated using the product-moment correlation coefficient ( $r$ value) (25), applied to the whole densitometric curves of the gel tracks $(8,28-30)$. Cluster analysis of the pairwise similarity values was performed using the

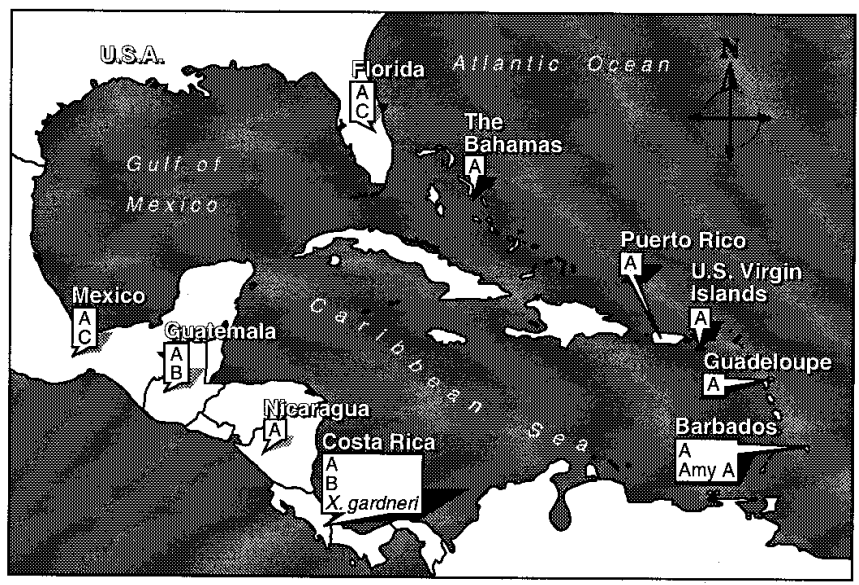

Fig. 1. Distribution of phenotypic groups of Xanthomonas campestris pv. vesicatoria in the Caribbean, Central America, Florida, and Mexico. Data for Bahamas, Florida, and Mexico came from other studies $(3,4,12)$.

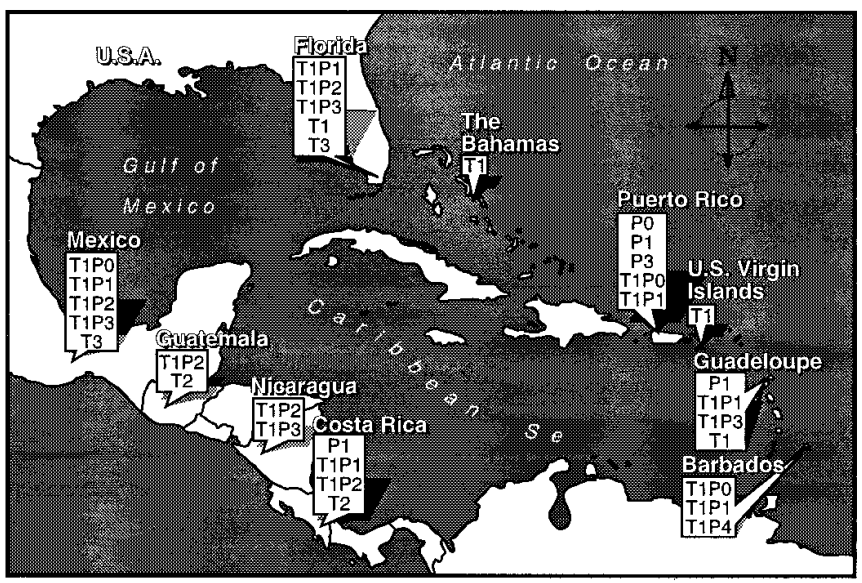

Fig. 2. Distribution of pathogenic races of Xanthomonas campestris pv. vesicatoria in the Caribbean, Central America, Florida, and Mexico. 
unweighted pair group method using arithmetic averages (37) clustering technique. Fingerprint patterns were reconstructed as described $(21,29,33)$.

\section{RESULTS}

Characterization of bacterial spot strains isolated from diverse locations by determining phenotypic group, pathogenic race, and sensitivity to copper and streptomycin. The characterization of 433 bacterial spot strains collected from different locations in the Caribbean and Central America revealed that group A strains were present in 29 out of the 32 fields examined (Tables 1 and 2). Group B strains were only detected in two fields in Central America (Fig. 1). No group C strains were identified in this large survey.

In the Barbados fields surveyed, 93\% of the strains were found to be resistant to copper and, except for the strains from field 6, sensitive to streptomycin (Table 1). All these strains were group A and were determined to be serovar A1 (Fig. 1) and tomato race 1 (T1) (Fig. 2). With the exception of strains from pepper field 8, the bacteria analyzed were phenotypically very similar. Furthermore, they were nonamylolytic, nonpectolytic, displayed the $32-\mathrm{kDa}$ protein band characteristic of A strains, belonged to carbon substrate utilization cluster II of the dendrogram (Fig. 3), and classified as pepper race P0 or P1. In contrast, 17 strains isolated from pepper field 8 were amylolytic, pectolytic, and appeared to belong

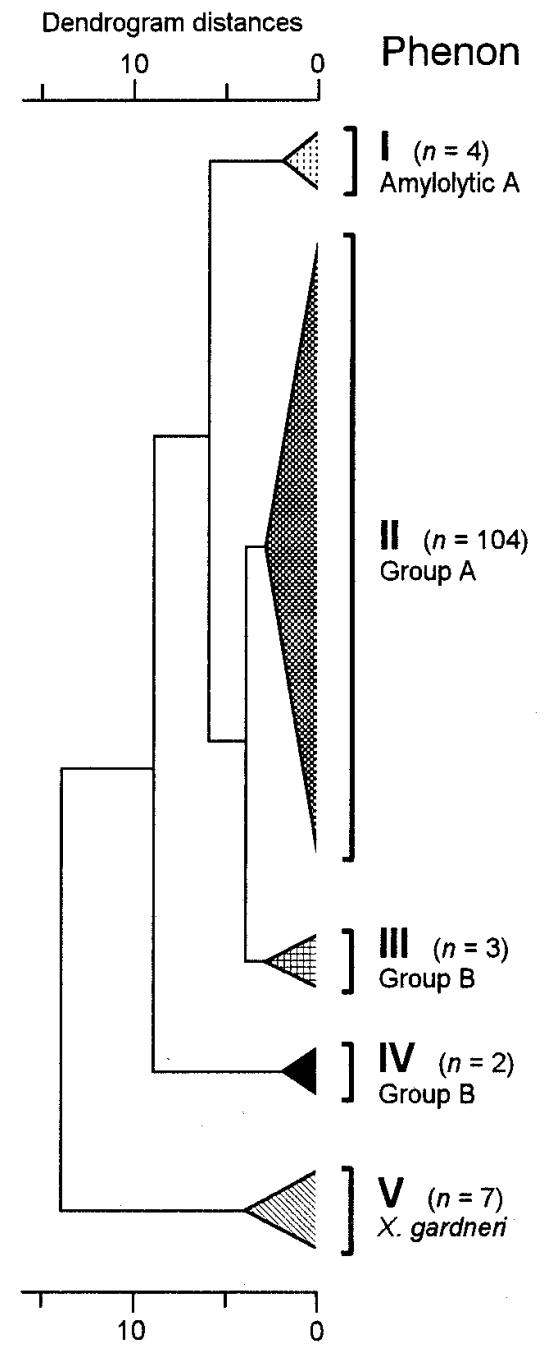

Fig. 3. Relationships among strains of Xanthomonas campestris pv. vesicatoria isolated from the Caribbean on the basis of utilization of carbon substrates available on GN Microplate (Biolog Inc., Hayward, CA). to race $\mathrm{P} 4$. These unusual strains were determined to be closely related to group A strains based on DNA-DNA hybridization (data not shown). Cluster analysis of metabolic fingerprints (Fig. 3) separated the amylolytic A strains from the typical group A strains, even though both groups oxidized cis-aconitic acid (Table 3). Protein profile analysis revealed that the amylolytic A strains lacked the $32-\mathrm{kDa}$ protein band; instead, they displayed a prominent $25-\mathrm{kDa}$ band (Table 2).

The population of strains from fields in Guadeloupe was quite homogeneous. Most strains (82/84) were resistant to copper and all were sensitive to streptomycin. All 82 strains were nonamylolytic and nonpectolytic; 22 strains were further tested and all of them displayed the 32-kDa protein band and their metabolic fingerprints clustered with the typical group A strains. One strain belonged to serovar A3 and the remaining belonged to serovar A1. Most of the strains were race T1P1 (Fig. 2).

Strains isolated from fields in the U.S. Virgin Islands were resistant to copper and streptomycin. None of these strains hydrolyzed starch or degraded pectate. Except for one of the strains, which belonged to serovar A1, all other strains were serovar A3. These strains belonged to race T1 (Fig. 2), displayed the 32-kDa protein band, and clustered with typical group A strains according to metabolic fingerprints.

In Puerto Rico, most strains from fields 1 to 3 belonged to serovar A1 group (41 A1 and $8 \mathrm{~A} 3$ ). However, in fields 4 to 6 , serovar A3 strains were found to predominate ( 3 A1 and 53 A3). Most strains $(103 / 105)$ in all six fields analyzed were resistant to copper. Interestingly, most type A1 strains (42/44) were sensitive to streptomycin, while most A3 strains (57/61) were resistant. All strains were nonamylolytic and nonpectolytic.

In Costa Rica, most isolates (62/64) were resistant to copper and more than half the strains were resistant to streptomycin. In fields 4 to 7 , all 42 strains isolated were typical group A strains (i.e., nonamylolytic, nonpectolytic, and belonging to serovar A1). However, in field 3, one group B strain was found (i.e., amylolytic, pectolytic, and serovar B0). The remaining 7 strains isolated from field 3 and 14 strains recovered from field 2 were phenotypically distinct from both groups A and B. Although these strains were serologically related to $X$. campestris pv. vesicatoria group B strains (serovar B1), they were unable to hydrolyze starch or degrade pectate.

In Nicaragua, the 37 strains isolated from two different fields all belonged to serovar A1 and were nonamylolytic and nonpectolytic. Furthermore, these strains were resistant to copper and streptomycin.

In Guatemala, the strains from field 11 comprised 1 serovar A1 strain, 5 serovar B1 strains, and 12 serovar B2 strains. The only strain recovered from field 16 belonged to group A (serovar A1).

TABLE 3. Differential utilization of carbon substrates by strains in each dendrogram cluster

\begin{tabular}{lrrrrr}
\hline & \multicolumn{5}{c}{ Cluster $^{\mathrm{y}}$} \\
\cline { 2 - 6 } Carbon source & \multicolumn{1}{c}{$\mathrm{I}$} & $\mathrm{II}$ & $\mathrm{III}$ & $\mathrm{IV}$ & $\mathrm{V}$ \\
\hline$N$-Acetyl-D-glucosamine & $100^{\mathrm{z}}$ & 100 & 100 & 100 & 14 \\
Glycogen & 100 & 0 & 33 & 0 & 0 \\
Cellobiose & 75 & 100 & 100 & 0 & 86 \\
D-Galactose & 100 & 82 & 100 & 50 & 0 \\
Gentiobiose & 0 & 100 & 100 & 100 & 0 \\
Lactulose & 100 & 84 & 33 & 0 & 0 \\
Acetic acid & 50 & 100 & 33 & 0 & 0 \\
cis-Aconitic acid & 100 & 100 & 0 & 0 & 14 \\
Glycyl-L-glutamic acid & 0 & 100 & 100 & 0 & 14 \\
Glycerol & 75 & 100 & 100 & 0 & 0 \\
D-Alanine & 100 & 100 & 100 & 0 & 0 \\
L-Proline & 0 & 100 & 33 & 0 & 71 \\
L-Threonine & 100 & 100 & 100 & 50 & 0 \\
\hline
\end{tabular}

y Clusters according to the Biolog dendrogram (Fig. 3). I = Amy A ( $n=4), \mathrm{II}=$ $\mathrm{A}(n=104), \mathrm{III}=\mathrm{B}(n=3), \mathrm{IV}=\mathrm{B}(n=2)$, and $\mathrm{V}=$ Xanthomonas gardneri $(n=7)$.

${ }^{\mathrm{z}}$ Percent of strains in the cluster that oxidize the substrate. 
Only three strains were resistant to copper, and the only serovar A1 strain was resistant to streptomycin.

Analysis of selected strains by phage sensitivity, protein profiles, and carbon substrate utilization. Further phenotypic analysis of 120 representative strains isolated from all regions confirmed the predominance of group A strains in the Caribbean basin (Tables 1, 2, and 3; Fig. 1). Based on the ability to oxidize cisaconitic acid (Table 3), cluster analysis using the microplate from Biolog (Fig. 3), and the presence of a diagnostic 32-kDa band in whole-cell protein profiles analyzed (Table 2), 104 strains were confirmed to be typical of group A. Five strains recovered from tomato fields in Central America (Costa Rica and Guatemala) cor-

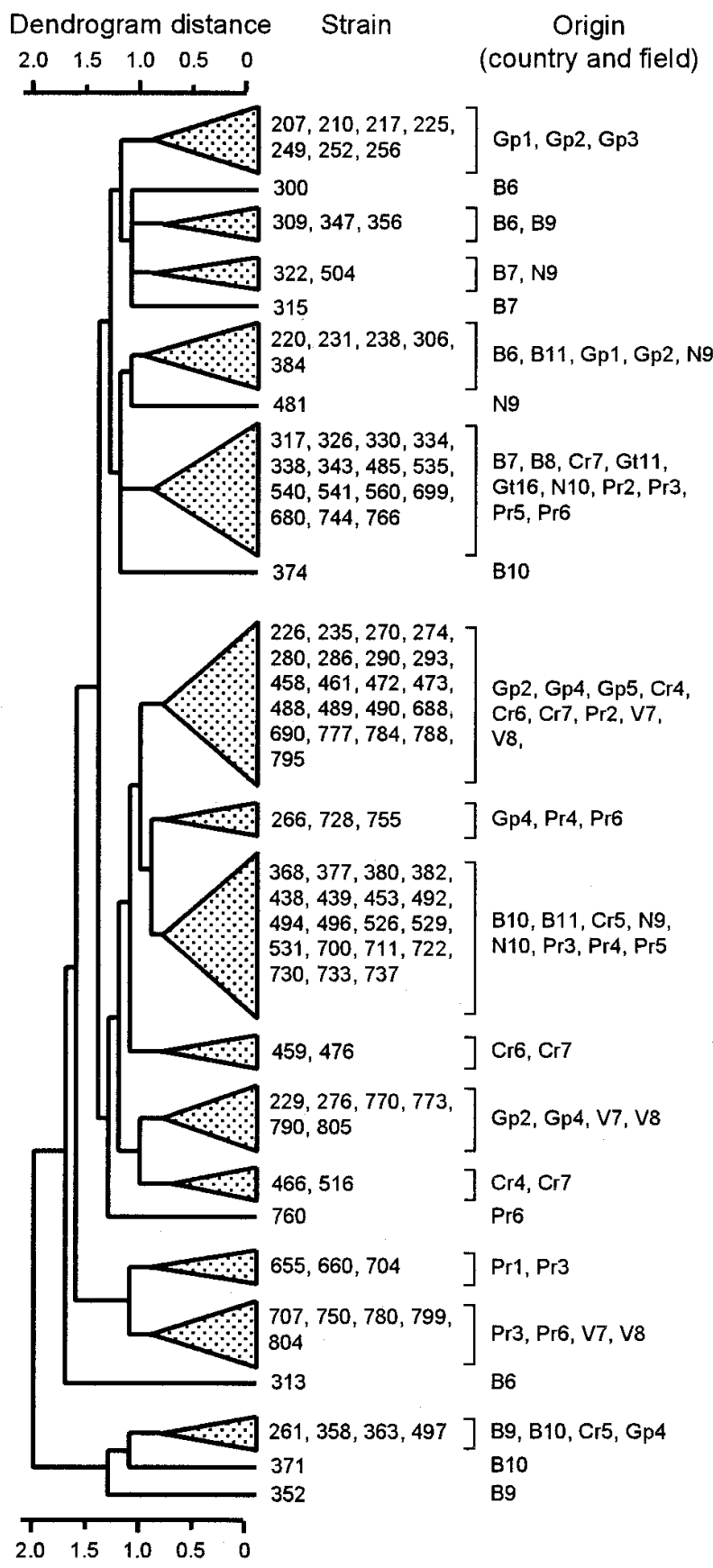

Fig. 4. Relationships among A strains of Xanthomonas campestris pv. vesicatoria isolated from the Caribbean on the basis of reactions to 26 bacteriophages to $X$. campestris pv. vesicatoria. Designation for country of origin of strains used in study is as follows: $\mathrm{B}=$ Barbados, $\mathrm{CR}=$ Costa Rica, $\mathrm{GP}=$ Guadeloupe, GT = Guatemala, $\mathrm{N}=$ Nicaragua, $\mathrm{PR}=$ Puerto Rico, and $\mathrm{V}=$ U.S. Virgin Islands. Number following country abbreviation designates field from which strain originated. responded to group $\mathrm{B}$, based on the presence of a $27-\mathrm{kDa}$ protein band (Table 1) and their inability to oxidize cis-aconitic acid (Table 3).

The reaction of individual strains to phage differed according to their group affiliation. None of the phages examined were found to be able to infect group B strains and atypical B strains from Costa Rica. These strains displayed a B-type serovar and shared a $27-\mathrm{kDa}$ protein band. In contrast, the phages were able to infect most strains in serovar A. The observed phage reactions were heterogeneous, and a cluster analysis of group A strains suggests the presence of a diversified strain population (Fig. 4). In most fields, strains were isolated that produced at least two different reaction patterns to the 26 phages. In several fields, such as Guadeloupe field 2 , strains were isolated that belonged to distantly related clusters.

Genetic diversity as determined by rep-PCR genomic fingerprinting. A subset of 63 representative strains from the Caribbean and 3 reference strains were subjected to rep-PCR genomic fingerprinting analysis. This analysis revealed the presence of four distinct genomic fingerprint groups (Fig. 5, A to D). The reference strains for group A (Xv 153), group B (Xv 1111), and group C (Xv 938) were clearly delineated when combined BOX-, ERIC-, and REP-PCR genomic fingerprint profiles were analyzed (Fig. 5, horizontal arrows). The majority of the Caribbean and Central American strains analyzed displayed a rep-PCR genomic fingerprint pattern highly similar to that observed with the group A reference strain (Xv 153). The group C reference strain (Xv 938) had several bands that comigrated with those of group A strains, but numerous polymorphisms revealed that this genomic fingerprint was distinct from all others. None of the Central American or Caribbean strains clustered with the group $\mathrm{C}$ strain, confirming the phenotypic data above. Two representative strains from Guatemala field 11 and one from Costa Rica field 3 have genomic fingerprints distinct from all group A strains but similar to Xv 1111 (group B), which agrees with the results of the phenotypic assays.

The fourth major group as determined by rep-PCR genomic fingerprinting (Fig. 5, group D) included three representative strains from Costa Rica fields 2 and 3. These strains were highly similar to one another but distinct from all other strains tested. The observation that 7 of the 21 Costa Rican strains could not be assigned phenotypically to either the A or B group (Tables 1 and 2) was confirmed by their differences based on carbon substrate utilization (Fig. 3, Table 3). Based on the phenotypic traits of X. gardneri (4) and DNA homology data (data not shown), these Costa Rican strains were identified as $X$. gardneri.

Although strains classified as group A shared numerous comigrating bands, several polymorphisms could be observed and cluster analysis resulted in the generation of five major subclusters within the population (Fig. 5, 1 to 5). Clusters 3 to 5 consisted of strains isolated from the Caribbean, with two exceptions, strains 453 from Nicaragua and 473 from Costa Rica. The majority of group A strains from Central America were in clusters 1 and 2. These two clusters also included six strains isolated from the Caribbean including one from Puerto Rico, two from Barbados, and three from Guadeloupe.

In several cases, clusters were observed consisting of strains that appeared to comprise a lineage with a recent common ancestor. For example, cluster 3 included four strains from Guadeloupe (270, 290, 286, and 229), eight strains from Puerto Rico or the Virgin Islands $(680,744,755,766,688,690,770$, and 777), five strains from the Virgin Islands or Puerto Rico (799, 711, 722, 700, and 699), and two strains from Barbados (300 and 306, in which banding patterns were highly similar to the group A reference strain $\mathrm{Xv}$ 153). In some cases, these lineages consisted of strains isolated from different fields or islands.

In several cases, virtually identical strains were isolated from the same field, suggesting that they form a clonal population. For example, the two amylolytic group A strains from Barbados field 8 (338 and 343) shared unique polymorphisms (Fig. 5, vertical ar- 
row head). Similar observations were noted for other field pairs such as two strains in cluster 4 from Virgin Island field 8 (790 and 795) and two strains in cluster 5 from Guadeloupe field 1 (217 and 220). In several locations, strains isolated within a single field belonged to different genomic groups or clusters. For example, two strains from Guatemala field 11 (456 and 469) were classified as group B strains, whereas a third strain (535) was clearly a group A strain and fell in cluster 1. Likewise, four closely related strains from Costa Rica (458, 461, 485, and 516), including one from field 7, were within cluster 2, whereas a second strain from field 7 was in cluster 4 and found to be highly similar to strains isolated from Puerto Rico.

The HR reactions on differential tomato lines distinguished strains according to the A and B groups. All group A strains, which were pathogenic on tomato, were race $T 1$. Two of the $B$ strains were race $\mathrm{T} 2$; the other three $\mathrm{B}$ strains induced a HR on both tomato genotypes. The $X$. gardneri strains were P1. The distribution of pathogenic races was as follows: Barbados (7 T1P0, 13 T1P1, and 4 T1P4); Costa Rica (17 P1, 3 T1P1, 3 T1P2, and 1 T2); Guadeloupe (1 P1, 18 T1P1, 2 T1P3, and 1 T1); Guatemala (2 T1P2 and 1 T2); Nicaragua (7 T1P2 and 3 T1P3); Puerto Rico (2 P0, 5 P1, 2 P3, 11 T1P0, and 3 T1P1); and the U.S. Virgin Islands (11 T1).

\section{DISCUSSION}

Over 400 xanthomonads isolated from tomato or pepper from 32 different fields in four Caribbean and three Central American countries were analyzed using phenotypic and genomic fingerprinting assays. The majority of strains were found to be typical group A strains that have recently been reclassified as $X$. axonopodis pv. vesicatoria (43). These strains had a rep-PCR genomic fingerprint similar to reference group A strain Xv 153 and typically were nonpectolytic and nonamylolytic, utilized cis-aconitic acid, expressed the 32-kDa protein (Table 4), and were lysed by one or more phages. All Central American group A strains belonged to serovar A1, whereas $44 \%$ of the Caribbean strains belonged to serovar A3 and $54 \%$ to serovar A1. Serovar A3 strains have not been found in Barbados, but a unique group of strains was found that was amylolytic and serologically similar to group A strains. DNA/DNA hybridization revealed that these are closely related to the amylolytic A strains isolated in Mexico (3). When two of these strains were included in the rep-PCR analysis, they were virtually identical to one another but could be distinguished from all other strains by the presence of a distinct polymorphism generated using the REP

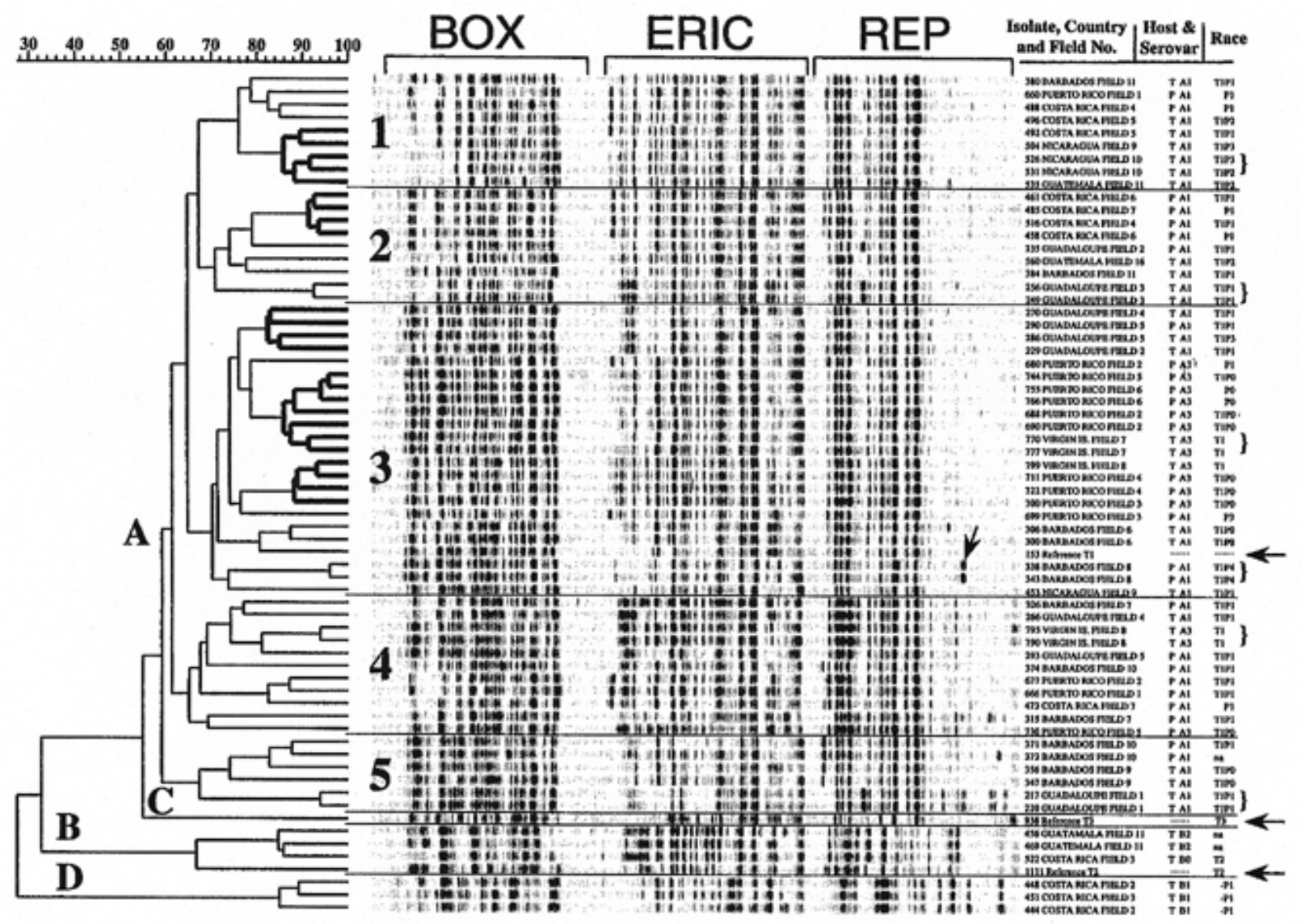

Fig. 5. Similarity of strains of Xanthomonas campestris pv. vesicatoria isolated from the Caribbean based on the presence and absence of bands generated using primers corresponding to repetitive extragenic palindromic sequences (REP), BOX1A sequences (BOX), and enterobacterial repetitive intergenic consensus sequences (ERIC) and analyzed using the product-moment correlation coefficient $(r)$. Group A strains formed five clusters, designated 1 to 5 . Arrows are used to designate reference strains and unique bands associated with two strains for the Barbados.

TABLE 4. Differential characteristics of the four Xanthomonas campestris pv. vesicatoria groups identified in the Caribbean and Central America

\begin{tabular}{|c|c|c|c|c|c|c|c|}
\hline \multirow[b]{2}{*}{ Phenotypic group } & \multicolumn{2}{|c|}{ Degradation } & \multicolumn{2}{|c|}{ Utilization } & \multirow[b]{2}{*}{ Group-specific protein } & \multirow[b]{2}{*}{ Biolog cluster } & \multirow[b]{2}{*}{ Serovar } \\
\hline & Starch & Pectate & cis-Aconitate & Gentobiose & & & \\
\hline A & $-z^{z}$ & - & + & - & $32 \mathrm{kDa}$ & II & $\mathrm{A} 1, \mathrm{~A} 3$ \\
\hline A1 & + & + & + & + & $25 \mathrm{kDa}$ & I & A1 \\
\hline D & - & - & $\mathrm{v}$ & - & $27 \mathrm{kDa}$ & V & B1 \\
\hline
\end{tabular}

$\mathrm{z}_{-}=$Negative reaction, $+=$positive reaction, and $\mathrm{v}=$ variable reaction. 
primers (Fig. 5, arrow). These strains had several unique phenotypic characteristics: race $\mathrm{P} 4$, unique Biolog microplate profile, and the presence of a $25-\mathrm{kDa}$ protein as compared with a typical 32or $27-\mathrm{kDa}$ protein band for the group A and B strains, respectively. However, these strains reacted with a bank of group A-specific phages and reacted like serovar A1 serologically. These amylolytic strains were placed in phenotypic group A1 (Table 4).

Two fields in Costa Rica and one in Guatemala contained group $\mathrm{B}$ strains that had rep-PCR genomic fingerprints similar to the representative group B strain, Xv 1111, which is currently the type strain for $X$. vesicatoria as classified by Vauterin et al. (43). The limited distribution of this group of strains in Central America and its absence in the Caribbean is in contrast to its frequent occurrence in the central United States (20) and South America (38). It is not clear whether the low incidence or absence of B strains in certain regions (e.g., Florida) is due to their ecological specificity or simply that they have not been introduced into these regions. This is a very important question, since the use of Hawaii 7998derived resistance is only effective against the T1 strains and not the $\mathrm{T} 2$ strains.

T3 strains were not isolated in this study despite the recent increase of this race in Florida (15) and its recent discovery in Mexico (3). It is possible that T3 strains were introduced into Florida on contaminated seed from Thailand; perhaps they have simply not been introduced to any of the countries surveyed in this study. rep-PCR showed that race T3 could be differentiated from all other races and that it appears to be most closely related to group A strains. This is in agreement with DNA/DNA reassociation assays (H. Bouzar and J. B. Jones, unpublished data) and demonstrates the utility of rep-PCR to detect this new race.

A significant result of our survey was to identify the unique strains from Costa Rica that were phenotypically and genomically distinct from all the other "vesicatoria" strains. DNA/DNA reassociation analysis revealed that this group of strains is most similar to the neotype strain for X. gardneri $(\mathrm{H}$. Bouzar and J. B. Jones, unpublished data). This is the first report of this species since it was first recorded by Sutic in 1957 (40). Again, the origin and relative importance of this species is not known.

The majority of races were found to be T1P1 and T1P3. P0 (North Carolina and Mexico), P2 (Guadeloupe and Florida), and P4 (Australia) are unusual pepper races $(3,5,10,16,24,31)$. Most strains were found to be copper resistant, and there was a high incidence of streptomycin resistance in most countries, except Barbados and Guadeloupe. The lack of streptomycin resistance in these countries may be due to limited or lack of use of the antibiotic as a foliar spray, and resistant strains may arise rapidly should the antibiotic be used routinely.

There was very little linkage among some of the phenotypic traits and the genomic fingerprint pattern of the pathogen. For example, there was no association between the rep-PCR fingerprint profiles within group A and sensitivity to phages or race designation. This is not surprising, because phage sensitivity is likely to change rapidly and, therefore, may not reflect the underlying genotype. A similar situation has been observed with serovar traits (35). Likewise, differences in the race of a pathogen apparently are not detectable using rep-PCR. A race change can occur by the loss of a plasmid carrying avirulence genes (e.g., race change from P1 to $\mathrm{P} 3$ ), inactivation of an avirulence gene by insertion of a transposable element such as IS476 (e.g., race change from P2 to P3) (17), or other mutations (41).

The rep-PCR genomic fingerprinting experiments suggest that certain lineages may have evolved or predominated in specific regions. The majority of the Caribbean strains fell within rep-PCR clusters 3 to 5 and, within these clusters, genetic lineages of recent descent and sharing a common ancestor were confined to one or two islands. Likewise, the majority of the Central American isolates fell within rep-PCR clusters 1 and 2. The occurrence of only two Central American lineages in the Caribbean, in contrast to the presence of six Caribbean lineages in Central America, suggests that there is a higher rate of migration of Caribbean lineages into Central America than vice versa. To further determine the association of specific lineages with geographic regions would require more intensive sampling and analysis.

Xanthomonas strains that incite bacterial spot of tomato or pepper in the Caribbean and Central America predominantly belong to one group (group A). This suggests that there should be some advantage to deploying Hawaii 7998-based resistant tomato cultivars, but only if such a program would be augmented by a vigilant effort to prevent the further introduction and spread of $\mathrm{T} 2$ strains throughout the region.

Deciphering the race composition of pepper strains depends on using differential hosts and could not be predicted by rep-PCR genomic fingerprinting. With the exception of strains isolated in Barbados field 8, pepper lines that have the $B s 2$ gene would be effective against the majority of strains found in this study. However, selective pressure has resulted in the selection of $a v r B s 2$ mutants (17) and the use of multilines may be a more durable approach to managing the disease and attempting to ensure durable resistance.

\section{ACKNOWLEDGMENTS}

This paper appeared as Florida Agricultural Experiment Station Journal Series no. R-6386. This research was supported by grant 90-34135-5164 from the USDA Special Research Grants/Tropical \& Subtropical Agricultural Research Program, research agreement 58-319R-1-031 from the USDA Office of International Cooperation and Development, the DOE (DE FG 0290ER20021), the NSF Center for Microbial Ecology (DIR 8809640), Heinz Inc., Roger Seeds Co., and the Consortium for Plant Biotechnology Research (DE-FC05-02OR22072). We thank J. Chun, P. M. Strickler, and J. Sudberry for their dedicated technical assistance. We also thank the following who helped in obtaining the strains: G. Ano, INRA, Guadeloupe; E. Bustamante, CATIE, Costa Rica; C. Cardona, St. Croix, U.S. Virgin Islands; D. T. Krigsvold, PROEXAG, Guatemala; D. Monterroso, CATIE-MIP, Nicaragua; L. W. O'Garro and P. Ward, University of West Indies, Barbados; D. Dardón Avila and V. Salguero, Instituto de Ciencias y Tecnología Agrícolas, Guatemala; and M. Zapata, University of Puerto Rico, Mayaguez.

\section{LITERATURE CITED}

1. Bouzar, H., Jones, J. B., and Hodge, N. C. 1993. Differential characterization of Agrobacterium species using carbon-source utilization patterns and fatty acid profiles. Phytopathology 83:733-739.

2. Bouzar, H., Jones, J. B., Minsavage, G. V., Stall, R. E., and Scott, J. W. 1994. Proteins unique to phenotypically distinct groups of Xanthomonas campestris pv. vesicatoria revealed by silver staining. Phytopathology 84:39-44.

3. Bouzar, H., Jones, J. B., Somodi, G. C., Stall, R. E., Daouzli, N., Lambe, R. C., Felix-Gastelum, R., and Trinidad-Correa, R. 1996. Diversity of Xanthomonas campestris pv. vesicatoria in tomato and pepper fields of Mexico. Can. J. Plant Pathol. 18:75-77.

4. Bouzar, H., Jones, J. B., Stall, R. E., Hodges, N. C., Minsavage, G. V., Benedict, A. A., and Alvarez, A. A. 1994. Physiological, chemical, serological, and pathogenic analyses of a worldwide collection of Xanthomonas campestris pv. vesicatoria strains. Phytopathology 84:663-671.

5. Cook, A. A., and Stall, R. E. 1982. Distribution of races of Xanthomonas vesicatoria pathogenic on pepper. Plant Dis. 66:388-389.

6. Dye, D. W., Starr, M. P., and Stolp, H. 1964. Taxonomic classification of Xanthomonas vesicatoria based upon host specificity, bacteriophage sensitivity, and cultural characteristics. Phytopathol. Z. 51:394-407.

7. Goode, M. J., and Sasser, M. 1980. Prevention-The key to controlling bacterial spot and bacterial speck of tomato. Plant Dis. 64:831-834.

8. Häne, B. G., Jäger, K., and Drexler, H. 1993. The Pearson product-moment correlation coefficient is better suited for identification of DNA fingerprinting profiles than band matching algorithms. Electrophoresis 14:967-972.

9. Hayward, A. C., and Waterston, J. M. 1964. Descriptions of Pathogenic Fungi and Bacteria. No. 20, "Xanthomonas vesicatoria." Commonw. Mycol. Inst., Kew, Surrey, England.

10. Hibberd, A. M., Persley, D. M., Nahrund, G. C., and Gillespie, D. 1989. Breeding disease-resistant capsicum for wide adaptation. Acta Hortic. 247:171-174. 
11. Hildebrand, D. C., Palleroni, N. J., and Schroth, M. N. 1990. Deoxyribonucleic acid relatedness of 24 xanthomonad strains representing 23 Xanthomonas campestris pathovars and Xanthomonas fragariae. J. Appl. Bacteriol. 68:263-269.

12. Jones, J. B., Bouzar, H., Somodi, G. C., Stall, R. E., Pernezny, K., ElMorsy, G., and Scott, J. W. 1998. Evidence for the preemptive nature of tomato race 3 of Xanthomonas campestris pv. vesicatoria in Florida. Phytopathology 88:33-38.

13. Jones, J. B., and Jones, J. P. 1985. The effect of bactericides, tank mixing time and spray schedule on bacterial leaf spot of tomato. Proc. Fla. State Hortic. Soc. 98:244-247.

14. Jones, J. B., Jones, J. P., Stall, R. E., and Zitter, T. A. 1991. Bacterial spot. Page 73 in: Compendium of Tomato Diseases. The American Phytopathological Society, St. Paul, MN.

15. Jones, J. B., Stall, R. E., Scott, J. W., Somodi, G. C., Bouzar, H., and Hodges, N. C. 1995. A third tomato race of Xanthomonas campestris pv. vesicatoria. Plant Dis. 79:395-398.

16. Kousik, C. S., and Ritchie, D. F. 1995. Isolation of pepper races 4 and 5 of Xanthomonas campestris pv. vesicatoria from diseased peppers in Southeastern U.S. fields. Plant Dis. 79:540.

17. Kousik, C. S., and Ritchie, D. F. 1996. Race shifts in Xanthomonas campestris pv. vesicatoria within a season in field-grown pepper. Phytopathology 86:952-958.

18. Leung, H., Nelson, R. J., and Leach, J. E. 1993. Population structure of plant pathogenic fungi and bacteria. Adv. Plant Pathol. 10:157-205.

19. Louws, F. J., Fulbright, D. W., Stephens, C. T., and de Bruijn, F. J. 1994. Specific genomic fingerprints of phytopathogenic Xanthomonas and Pseudomonas pathovars and strains generated with repetitive sequences and PCR. Appl. Environ. Microbiol. 60:2286-2295.

20. Louws, F. J., Fulbright, D. W., Stephens, C. T., and de Bruijn, F. J. 1995. Differentiation of genomic structure by rep-PCR fingerprinting to rapidly classify Xanthomonas campestris pv. vesicatoria. Phytopathology 85: 528-536.

21. Louws, F. J., Schneider, M., and de Bruijn, F. J. 1997. Assessing genetic diversity of microbes using repetitive sequence-based PCR (rep-PCR). Pages 63-94 in: Nucleic Acid Amplification Methods for Analysis of Environmental Microbes. G. Toronzos, ed. Technimic Publishing Co., Inc., Lancaster, PA.

22. Marco, G. M., and Stall, R. E. 1983. Control of bacterial spot of pepper initiated by strains of Xanthomonas campestris pv. vesicatoria that differ in sensitivity to copper. Plant Dis. 67:779-781.

23. Minsavage, G. V., Dahlbeck, D., Whalen, M. C., Kearney, B., Bonas, U., Stakawicz, B. J., and Stall, R. E. 1990. Gene-for-gene relationships specifying disease resistance in Xanthomonas campestris pv. vesicatoria-pepper interactions. Mol. Plant-Microbe Interact. 3:41-47.

24. O'Garro, L. W., and Tudor, S. 1994. Contribution of four races of Xanthomonas campestris pv. vesicatoria to bacterial spot in Barbados. Plant Dis. 78:88-90.

25. Pearson, K. 1926 On the coefficient of racial likeness. Biometrika 18: 105-117.

26. Pohronezny, K., Stall, R. E., Canteros, B. I., Kegley, M., Datnoff, L. E., and Subramanya, R.1992. Sudden shift in the prevalent race of Xanthomonas campestris pv. vesicatoria in pepper fields in southern Florida. Plant Dis. 76:118-120.

27. Pohronezny, K., and Volin, R. B. 1983. The effect of bacterial spot on yield and quality of fresh market tomatoes. HortScience 18:69-70.

28. Rademaker, J. L. W., and de Bruijn, F. J. 1997. Characterization and classification of microbes by rep-PCR genomic fingerprinting and computer assisted pattern analysis Pages 151-171 in: DNA Markers: Protocols, Applications and Overviews. G. Caetano-Anolles and P. M. Gresshoff, eds. John Wiley \& Sons, Inc., New York.

29. Rademaker, J. L. W., Louws, F. J., and de Bruijn, F. J. 1998. Characterization of the diversity of ecologically important microbes by rep-PCR fingerprinting. Pages 1-26 in: Molecular Microbial Ecology Manual, Supplement 3. A. D. L. Akkermans, J. D. van Elsas, and F. J. de Bruijn, eds. Kluwer Academic Publishers, Dordrecht, the Netherlands.

30. Rademaker, J. L. W., Louws, F. J., Rossbach, U., and de Bruijn, F. J. Computer assisted pattern analysis of electrophoretic fingerprints and database construction. In: Molecular Microbial Ecology Manual, Supplement 4. A. D. L. Akkermans, J. D. van Elsas, and F. J. de Bruijn, eds. Kluwer Academic Publishers, Dordrecht, the Netherlands. In press.

31. Ritchie, D. F., and Dittapongpitch, V. 1991. Copper- and streptomycinresistant strains and host differentiated races of Xanthomonas campestris pv. vesicatoria in North Carolina. Plant Dis. 75:733-736.

32. Sahin, F., and Miller, S. A. 1995. First report of pepper race 6 of Xanthomonas campestris pv. vesicatoria, causal agent of bacterial spot of pepper. Plant Dis. 79:1188.

33. Schneider, M., and de Bruijn, F. J., 1996. Rep-PCR mediated genomic fingerprinting of Rhizobia and computer-assisted phylogenetic analysis. World J. Microbiol. Biotechnol. 12:163-174.

34. Scott, J. W., and Jones, J. B. 1986. Sources of resistance to bacterial spot (Xanthomonas campestris pv. vesicatoria (Doidge) Dye) in tomato. HortScience 21:304-306.

35. Selander, R., Smith, N. H., Li, J., Beltran, P., Ferris, K. E., Kopecko, D. J., and Rubin, F. A. 1992. Molecular evolutionary genetics of the cattleadapted serovar Samlmonella dublin. J. Bacteriol. 174:3587-3592.

36. Sherf, A. F., and MacNab, A. A. 1986. Vegetable Diseases and Their Control. John Wiley \& Sons, New York.

37. Sneath, P. H. A., and Sokal, R. R. 1973. Numerical Taxonomy. Freeman, San Francisco.

38. Stall, R. E., Beaulieu, C., Egel, D., Hodge, N. C., Leite, R. P., Minsavage, G. V., Bouzar, H., Jones, J. B., Alvarez, A. M., and Benedict, A. A. 1994. Two genetically diverse groups of strains are included in a pathovar of Xanthomonas campestris. Int. J. Syst. Bacteriol. 44:47-53.

39. Stall, R. E., Loschke, D. C., and Jones, J. B. 1986. Linkage of copper resistance and avirulence loci on a self-transmissible plasmid in Xanthomonas campestris pv. vesicatoria. Phytopathology 76:240-243.

40. Šutic, D. 1957. Bakterioze Crvenog Patlidzana. [Tomato bacteriosis]Posebna Izd. Inst. Zasht. Bilja, Beograd [Spec. Edit. Inst. Plant Prot., Beograd] 6. Rev. Appl. Mycol. 36:734-735.

41. Swords, K. M. M., Dahlbeck, D., Kearney, B., Roy, M., and Staskawicz, B. J. 1996. Spontaneous and induced mutations in a single open reading frame alter both virulence and avirulence in Xanthomonas campestris pv. vesicatoria avrBs2. J. Bacteriol. 178:4661-4669.

42. Thayer, P. L., and Stall, R. E. 1961. A survey of Xanthomonas vesicatoria resistance to streptomycin. Proc. Fla. State Hortic. Soc. 75:163-165.

43. Vauterin, L., Hoste, B., Kersters, K., and Swings, J. 1995. Reclassification of Xanthomonas. Int. J. Syst. Bacteriol. 45:472-489.

44. Versalovic, J., Schneider, M., de Bruijn, F. J., and Lupski, J. R. 1994. Genomic fingerprinting of bacteria using repetitive sequence-based polymerase chain reaction. Methods Mol. Cell. Biol. 5:25-40.

45. Wang, J. F., Jones, J. B., Scott, J. W., and Stall, R. E. 1990. A new race of the tomato group of strains of Xanthomonas campestris pv. vesicatoria. (Abstr.) Phytopathology 80:1070. 